\title{
Genetic variability of attachment (G) and Fusion (F) protein genes of human metapneumovirus strains circulating during 2006-2009 in Kolkata, Eastern India
}

\author{
Anurodh S Agrawal, Tapasi Roy, Swati Ghosh, Mamta Chawla-Sarkar ${ }^{*}$
}

\begin{abstract}
Background: Human metapneumovirus (hMPV) is associated with the acute respiratory tract infection (ARTI) in all the age groups. However, there is limited information on prevalence and genetic diversity of human metapneumovirus (hMPV) strains circulating in India.

Objective: To study prevalence and genomic diversity of hMPV strains among ARTI patients reporting in outpatient departments of hospitals in Kolkata, Eastern India.

Methods: Nasal and/or throat swabs from 2309 patients during January 2006 to December 2009, were screened for the presence of hMPV by RT-PCR of nucleocapsid (N) gene. The $\mathrm{G}$ and F genes of representative hMPV positive samples were sequenced.

Results: 118 of $2309(5.11 \%)$ clinical samples were positive for hMPV. The majority ( $\approx 80 \%)$ of the positive cases were detected during July-November all through the study period. Genetic analysis revealed that $77 \%$ strains belong to A2 subgroup whereas rest clustered in B1 subgroup. G sequences showed higher diversity at the nucleotide and amino acid level. In contrast, less than $10 \%$ variation was observed in $\mathrm{F}$ gene of representative strains of all four years. Sequence analysis also revealed changes in the position of stop codon in $G$ protein, which resulted in variable length (217-231 aa) polypeptides.

Conclusion: The study suggests that approximately 5\% of ARTI in the region were caused by hMPV. This is the first report on the genetic variability of $G$ and $F$ gene of hMPV strains from India which clearly shows that the $G$ protein of hMPV is continuously evolving. Though the study partially fulfills lacunae of information, further studies from other regions are necessary for better understanding of prevalence, epidemiology and virus evolution in Indian subcontinent.
\end{abstract}

\section{Background}

Acute Respiratory tract infections (ARTI) are a leading cause of morbidity and mortality worldwide [1]. Human metapneumovirus (hMPV), genus Metapneumovirus, family paramyxoviridae first identified in the Netherlands [2], is an important etiological agent of acute respiratory tract infection in almost all age groups. Subsequently it has been identified all over the world [3-6]. Morphologically, hMPV consists of a negative-sense,

\footnotetext{
* Correspondence: chawlam70@gmail.com

Division of Virology, National Institute of Cholera and Enteric Diseases, P-33, C.I.T. Road Scheme XM, Beliaghata, Kolkata-700010, India
}

single stranded and non Segmented RNA that encodes at least 9 distinct proteins [7]. Among them, the two major transmembrame glycoproteins, G and F, stimulate the production of protective immune responses, and therefore, are antigenically significant [8]. F protein promotes fusion of the viral and cell membrane while $G$ protein mediates virus binding to the cell receptor [9].

Genetic analysis on the basis of N, M and F genes have classified hMPV into two distinct groups or genotypes A and B [10-13]. Both genotypes are known to be prevalent throughout the world and circulate in a single season with the switching of predominant group in 
successive seasons $[3,12,14-16]$. Unlike the relatively conserved $\mathrm{F}$ protein (95\% identity at the amino acid level between group A and B), the G protein is highly variable with only $53 \%$ amino acid homology between group A and B $[17,18]$.

In developing countries like India, approximately 0.5 million children $<5$ years of age die due to ARTI [19-21]. We have previously reported prevalence of Influenza A (11 $\pm 1 \%)$, influenza B $(5.5 \pm 0.5 \%)$ and RSV $(7.5 \pm 1 \%)$ among outdoor patients in Kolkata [22,23]. Inspite of its significance as an important respiratory pathogen, there is no information on prevalence and genetic diversity of hMPV strains in India except for one report from Northern India [24]. To partially fulfill this lacuna, the study was done to analyze the extent of genetic variation and the circulation pattern of hMPV in Kolkata during 2006-2009.

\section{Methods}

\section{Sampling site and Study Population}

The study was conducted among patients of all age group exhibiting fever and 2 or more symptoms of ARTI (cold/ cough, sore throat, myalagia, body ache) from the outdoor patient ward of hospitals in Kolkata as reported previously [23]. None of these patients were hospitalized. Nasal and/or throat swabs were collected from 2309 patients and were transported in viral transport media (VTM) to the laboratory. The study was approved by the Institutional Ethical Committee and the informed consent was taken from patients or their guardians.

\section{Extraction of viral RNA}

RNA was extracted from $200 \mathrm{ul}$ clinical samples using commercially available RNeasy Mini Kit (Qiagen GmbH, Hilden, Germany) as per manufacturer's instructions.

\section{Reverse transcription and PCR}

For initial screening, amplification of a 416 bp portion of nucleoprotein $(\mathrm{N})$ gene was carried out using primers hmpv1 and hmpv2 by RT-PCR as described earlier [25]. All $\mathrm{N}$ positive samples were further amplified by using previously described $G$ and $F$ gene specific primers $[12,24]$. The resulting PCR products were purified with a Qiagen PCR purification Kit.

\section{Sequence and sequence analysis}

Nucleotide (nt.) sequencing of full length $\mathrm{G}$ gene and partial F gene (nt.1-nt.805) was carried out by using ABI Prism Big Dye Terminator v3.1 Cycle Sequencing Ready Reaction Kits in an ABI Prism 3100 Genetic Analyzer (PE Applied Biosystems, Foster City, California, U.S.A) using gene specific forward and reverse primers. Potential N'- and/or O'- glycosylation site/s were predicted by using NetNGlyc 1.0 and NetOGlyc v.3.1 software
$[26,27]$. The multiple and pair wise alignment of deduced amino acid (aa) sequences were performed by using CLUSTAL W software and phylogenetic trees were generated by the neighbor-joining method with the MEGA 5 software as described earlier [28].

\section{Nucleotide sequence database accession numbers}

The hMPV sequences for the $22 \mathrm{G}$ and $8 \mathrm{~F}$ genes analyzed in this study have been deposited in GenBank under the accession number HQ599198-HQ599227.

\section{Results}

\section{Prevalence \& age distribution of hMPV}

A total of 2309 samples were screened during January 2006 to December 2009 by RT-PCR based amplification of the relatively conserved $\mathrm{N}$ gene. Although the age of the patients ranged from 1 month to 50 years, most $(\geq 78 \%)$ were below 5 years of age (Table 1$)$. The screening results were confirmed by sequencing and BLAST analysis of $\mathrm{N}$ gene amplicon. hMPV was identified in $118(5.11 \%)$ samples in four years. $32(6.32 \%)$ of the 506 samples in 2006, 27 (4.46\%) of 605 samples in 2007, 41 (5.84\%) of 702 samples in 2008 and 18 (3.63\%) of 496 samples in 2009 were positive for hMPV.

The hMPV positive samples were found at low frequency $(0.5-1 \%)$ throughout the year but the majority $(\approx 80 \%)$ of the hMPV positive samples were detected during July-November correlating positively with rainfall and high humidity.

\section{Phylogenetic and antigenic analysis of G protein}

Phylogenetic analysis of 22 Kolkata strains (five representative strains from each year), confirmed two main genetic lineages $A$ and $B$. Each lineage $A$ and $B$ was further divided into 2 sub-lineage A1 \& A2 and B1 \& $B 2$ respectively (Figure 1 ). Interestingly, all the Kolkata strains clustered with A2 and B1 sub-lineage only (Figure 1). During 2006 and 2007, both sub group A2 and B1 co-circulated, with $77 \%(n=59)$ of the circulating strains belonging to A2 subgroup. Of $32 \mathrm{hMPV}$ positive samples in 2006, 26 were as subgroup A2 and 6 as subgroup B1, whereas in 2007, 27 were A2-positive and 8 were $\mathrm{B} 1$ positive strains. Interestingly no $\mathrm{B} 1$ strains were found in 2008 and 2009 and subgroup A2 remained as dominant strain throughout the study.

Sequence analysis of the complete ORF of G protein, revealed homology ranging from $53.8-56.4 \%$ at nt level

Table 1 Prevalence of hMPV infection in different age groups among outpatients $(n=2309)$

\begin{tabular}{ccccc}
\hline $\begin{array}{c}\text { Age Group/ } \\
\text { Virus prevalence }\end{array}$ & $\begin{array}{c}\mathbf{0 - 1} \text { year } \\
\mathbf{n}=\mathbf{4 4 9}\end{array}$ & $\begin{array}{c}\mathbf{1 - 2} \text { year } \\
\mathbf{n}=\mathbf{7 8 2}\end{array}$ & $\begin{array}{c}\mathbf{2 - 5} \mathbf{y r} \\
\mathbf{n}=\mathbf{6 3 2}\end{array}$ & $\begin{array}{c}\mathbf{2 1 5} \mathbf{y r} \\
\mathbf{n}=\mathbf{4 4 6}\end{array}$ \\
\hline hMPV & $4.23 \%$ & $5.37 \%$ & $7.28 \%$ & $2.47 \%$ \\
\hline
\end{tabular}




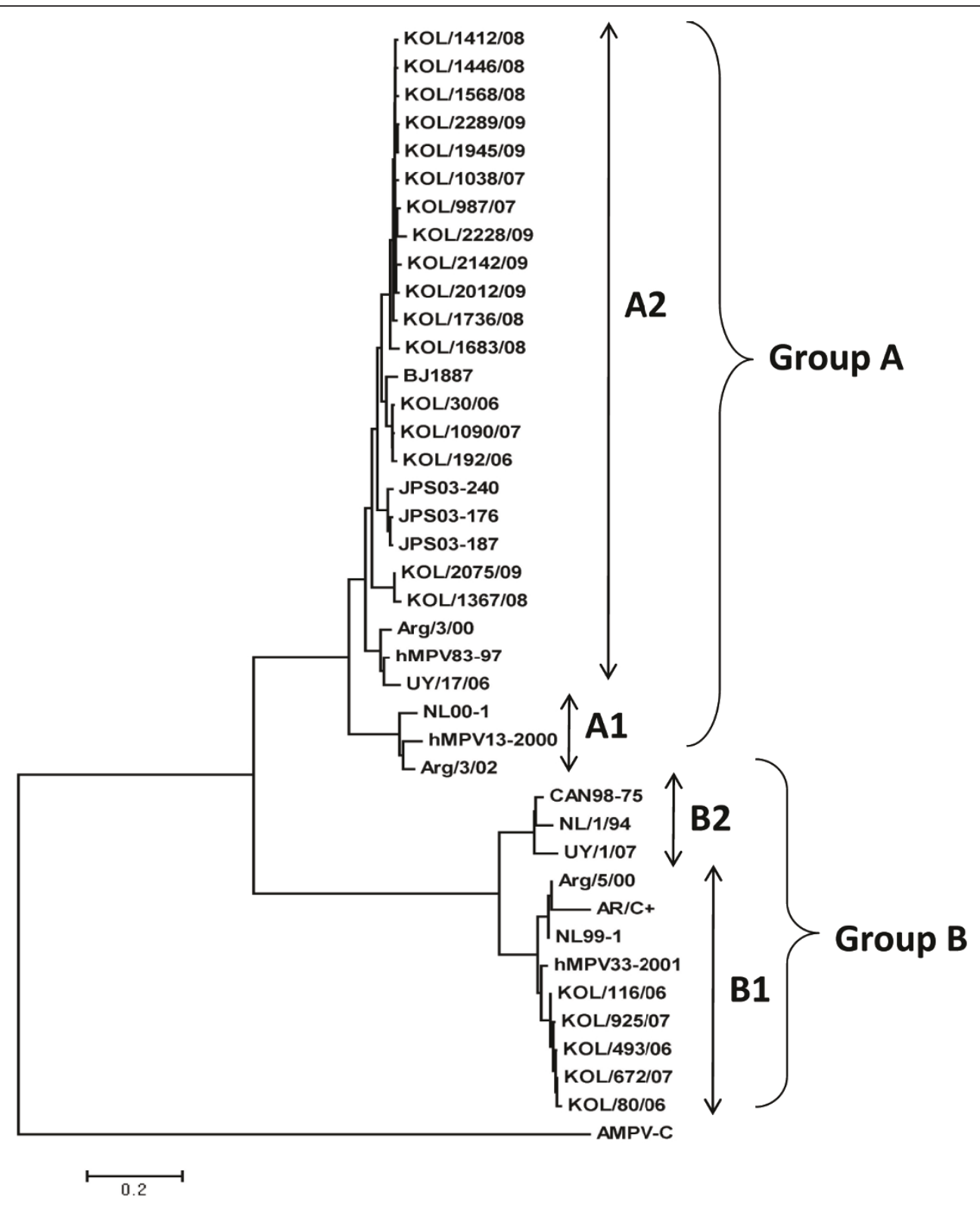

Figure 1 Phylogenetic analysis of the complete G gene of 22 hMPV Kolkata strains. Phylogenetic analysis of nt. sequences of hMPV group $\mathrm{A}$ and $\mathrm{B}$ strains from Kolkata (named with the prefix KOL followed by sample number and the year of collection) with that of other hMPV strains from different subgroups. Trees were built using neighbor-joining algorithm through MEGA 4 program. The tree was rooted with cognate stretch of G gene of strain AMPV-C (GenBank accession number AY198394).

and $34.1-35.9 \%$ at the aa level between the members of group A and B isolates. Sub group B1 strains shared high percentage of homology with the prototype strain NL/1/99 \{91.8\%-92.6\% (nt.); 89.1\%-90.0\% (aa)\}, whereas subgroup A2 strains revealed homology with the prototype strain CAN97-83 \{84.5\%-90.8\% (nt.); 76\%-86.3\% (aa)\}.

The alignment of deduced aa sequence of $\mathrm{G}$ protein of Kolkata strains with their prototype strains revealed that intracellular and transmembrane regions were highly conserved across the strains (Figure 2 and Figure 3). Most of the aa changes were observed in extracellular domain due to nt substitution and insertion. Changes in position of stop codon have been observed among strains of different subgroups (nt 658 (UAG); nt 652 (UAA), nt 685 (UAG), nt 694 (UGA)\}, which correspond to variable lengths in polypeptides. Strains from subgroup A2 used two different stop codons resulting in $\mathrm{G}$ proteins of 217aa (UAA), 219aa (UAG) and 228aa (UAG) (Figure 2), whereas subgroup B1 strains 


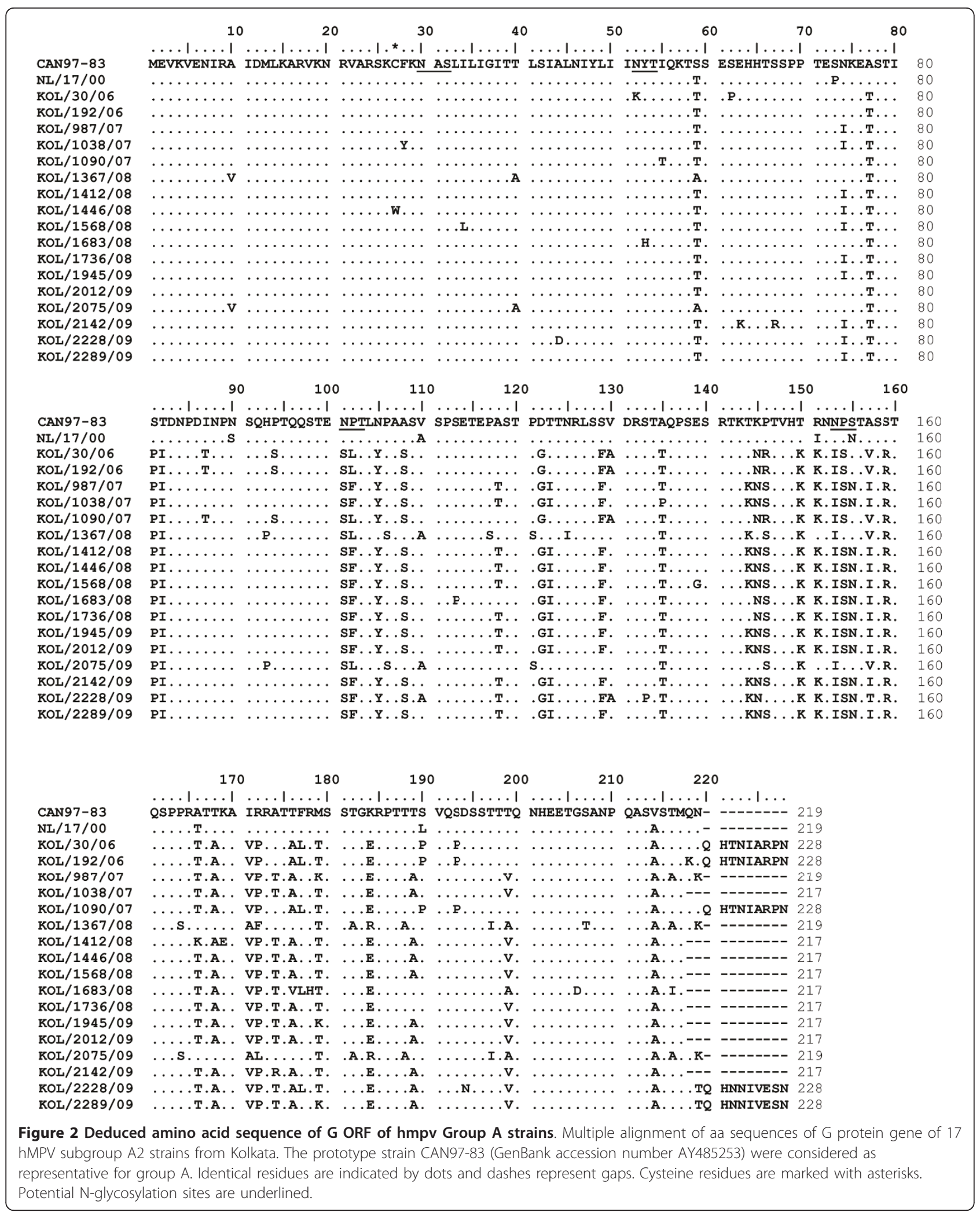






terminated at UGA stop codon and exhibited protein of 231 aa in length (Figure 3). For both the subgroup A2 and B1, a cysteine residue at position 27 is strictly conserved among all isolates in the intracellular domain except in one strain Kol/1446/08 which did not contain any cysteine residue. The $\mathrm{G}$ ectodomain also has a high content of proline residues, ranging from $7.8 \%$ for group $\mathrm{B}$ to $10 \%$ for group $\mathrm{A}$, which could contribute to an extended, unfolded secondary structure.

The $G$ protein gene sequenced in this study exhibited high content of serine and threonine residues that are potential O-linked sugar acceptors in both subgroups A2 and B1. Serine and threonine content of group A and group B strains was in the range $34.2-37.72 \%$ and 29.4-31.18\% respectively. The program NetOglyc v. 3.1 predicted 45 to 55 serine and threonine residues to be potentially $\mathrm{O}$-glycosylated with score predictors (G scores) of between 0.5 and 0.8 . All the predicted O-glycosylation sites were located in the extracellular region of the subgroup A2 and B1.

The number of $\mathrm{N}$-linked glycosylation site present in the $\mathrm{G}$ protein from different subgroup varied from two to six, and only one conserved site (aa 30) at the junction of the intracellular and transmembrane domain $[10,29]$. The rest of the sites showed subgroup specific conservation: sites 101, 169, 181 \& 188 were conserved in all the B1 strains whereas site 52, 145 and 152 was conserved among all the strains of subgroup A2. The predicted N-linked glycosylation sites at aa 52 (subgroup A2) and aa 30 (subgroup B1) exhibited high score of 0.7 . Only strain Kol/30/06 lacked the potential site at aa 52 whereas Kol/1367/08 and Kol/2075/09 had lost sites at aa 145 and 152 .

\section{Analysis of the F-gene}

Out of 118 hMPV positive Kolkata strains, F-gene was partially sequenced from positive patients covering throughout the study period. Blast analysis and sequence alignment revealed very little difference ( $\geq 98 \%$ homology) among the strains. Thus the phylogenetic analysis of the F-gene fragment was done with only 8 representative Kolkata strains (two strains per year). The Kolkata strains clustered with A2 (six strains) and B1 (two strains) sub-lineage strains NL/17/00 and NL/1/99 respectively (Figure 4). At the nt level, Kolkata strains shared higher percentage of homology with subgroup B1 prototype strain NL/1/99 (98.1\%) than the A2 subgroup strain CAN97-83 (96.05-96.8\%). Amino acid alignment of eight partial hMPV F gene (295 aa long) was compared with the prototype strains from Canada and the Netherland (see Additional file 1). For both the subgroup cysteine residues were conserved at position $28,60,182,283$ and 292 which could be involved in proper folding of $\mathrm{F}$ monomer, as been suggested for 


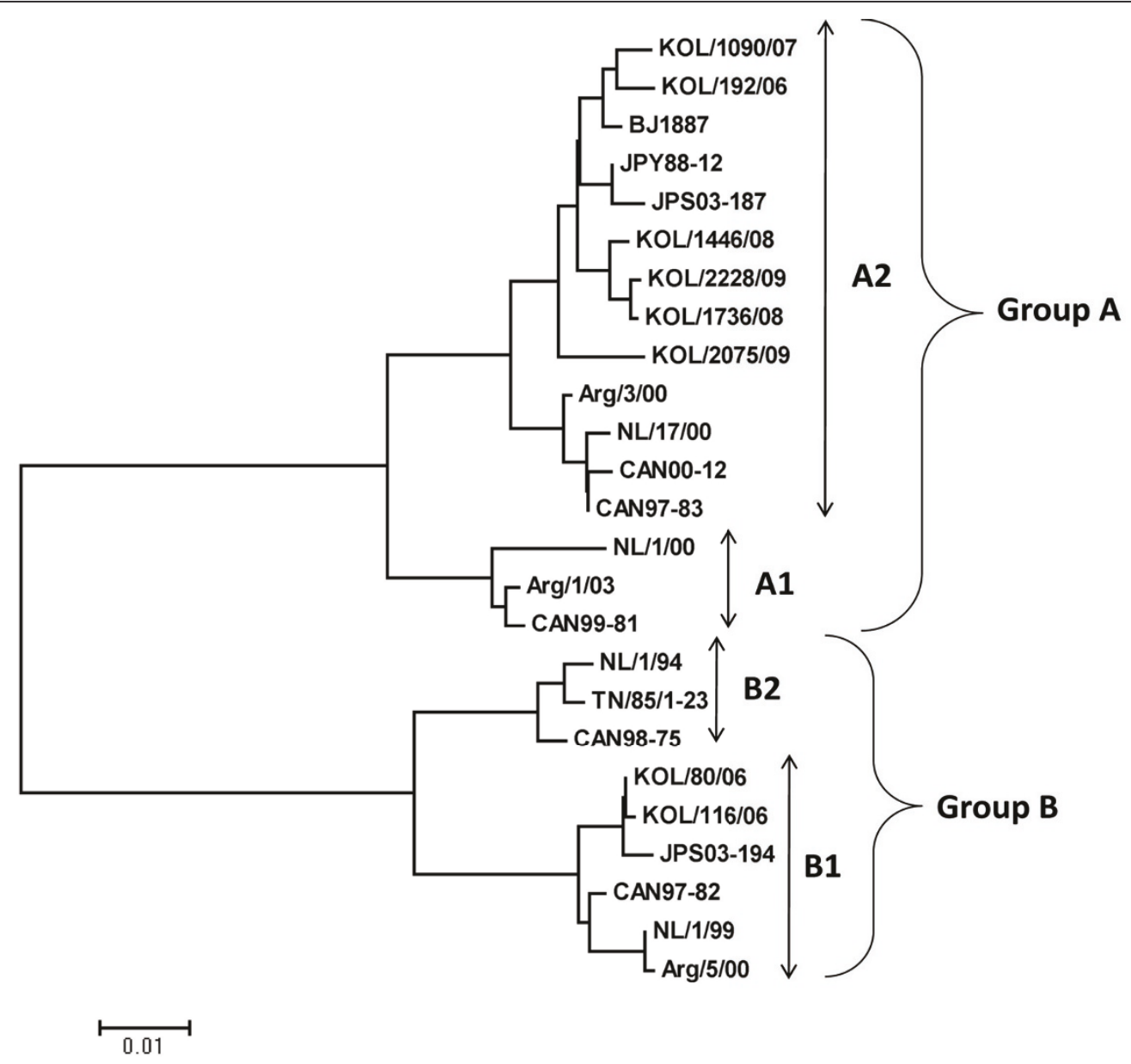

Figure 4 Phylogenetic analysis of the partial F gene of 8 hMPV Kolkata strains. Phylogenetic analysis of nt. sequences of hMPV group A and B strains from with that of other hMPV strains. Trees were built using neighbor-joining algorithm through MEGA 4 program. Strains from different subgroups were included in analysis.

hRSV [30]. Some of the important aa changes were subgroup specific which differentiated group A from group B (Table 2).

\section{Discussion}

In developing countries like India, the mortality and morbidity risk due to ARTI can be 30 times higher than in developed countries [31]. In spite of its importance, very few reports on etiology of ARTI cases are available [22-24]. hMPV is an important cause of ARI, which has been found in both healthy and immunocompromised patients [32,33]. The present study (2006-2009) provided vital insights into the epidemiology and genomic diversity of hMPV strains circulating among patients in Kolkata city, eastern India. To our knowledge, this is the first report on genetic diversity of hMPV strains based on G and $\mathrm{F}$ gene sequences from India.

To detect hMPV, initially $\mathrm{N}$ gene was chosen as it is highly conserved and has been used in previous studies $[33,34]$. RT-PCR based detection revealed a significant rate $(118 / 2309)$ of infection among outpatients with ARI. Of 118 positives, two samples had dual infection with RSV though no differences in clinical symptoms were observed. Compared with Influenza A $(11 \pm 1 \%)$ and

Table 2 List of subgroup specific amino acid changes in the representative Kolkata strains, isolated from 2006-2009

\begin{tabular}{|c|c|c|c|c|c|c|c|c|c|c|c|c|}
\hline $\begin{array}{l}\text { Position/ } \\
\text { Subgroup }\end{array}$ & 61 & 122 & 135 & 139 & 143 & 167 & 175 & 179 & 185 & 233 & 286 & 296 \\
\hline$A 2$ & $A$ & V & $\mathrm{T}$ & $\mathrm{N}$ & K & $D$ & $R$ & K & $D$ & $\mathrm{~N}$ & V & $K$ \\
\hline B1 & $\mathrm{T}$ & 1 & $\mathrm{~N}$ & $G$ & Q & $E$ & $S$ & $\mathrm{R}$ & $A$ & $Y$ & 1 & $N$ \\
\hline
\end{tabular}


RSV $(7.5 \pm 1 \%)$, an average $5.11 \%(4.6 \%-6.3 \%)$ positivity of hMPV was observed among the same study group $[22,23]$. This is significantly higher compared to reports from Canada (2.3\%), England (2.2\%) and USA (4.5\%) $[4,35,36]$, but is lower compared to frequency reported from the Netherlands (10\%), Australia (9.7\%) and Chile $(5.4 \%)[2,16,37]$. These variations in detection rates could be attributed to factors such as study population, seasonality and methods for detection. Majority of hMPV was detected from July to Nov (monsoon and autumn), which is similar to previous reports [32,38], but contrary to reports from New Delhi, India and temperate countries $[6,24,39]$, where the high incidence was observed in cold season. This is consistent with seasonality of influenza viruses which follow different seasonality between tropical and temperate countries [40].

Due to similarity between RSV and hMPV, we analyzed genetic diversity of both $\mathrm{F}$ and $\mathrm{G}$ surface glycoproteins because i) they are two major targets for neutralizing and protective immunity in RSV [8], ii) hMPV F gene is the major antigenic determinant and is classified worldwide into the context of genetic lineages $[5,35,41]$, iii) the G protein has been described as the most variable gene product among hMPV like the G protein of RSV $[11,18,29]$.

Phylogenetic analysis based on nt sequences of $\mathrm{G}$ and $\mathrm{F}$ gene with the representative strains demonstrated the existence of two group (A and B) and two subgroup A2 and B1. The study demonstrated high prevalence of subgroup A2 (77\%) than subgroup B1 (23\%) infection. Both group A and B viruses co-circulated for year 2006-07 but later group B virus disappeared. Similar to previous studies [11,29], the G gene sequence alignment showed extensive nt (53.8-56.1\%) and aa (34.2-35.9\%) variation between these two groups. In addition different length of $G$ polypeptide in strains belonging to different subgroup was also observed due to the usage of different stop codon $[5,42,43]$. Further studies are required to know whether the changes in stop codon are lineage specific and/or associated with the emergence of new evolutionary lineages, as suggested for RSV [44-46]. On the other hand, accumulation of sporadic aa substitutions and presence of additional and/or absence of N-'and/or O'- glycosylation sites in subgroup A2 and B1 strain from Kolkata provided evidences for constant mutation events which could be either critical for evading immune response/s or may confer enhanced stability that favor gradual establishment of certain local strains over others.

\section{Conclusion}

Since there was only one report on genetic heterogeneity of hMPV strains from northern India, it was extremely difficult to assess the current status of heterogeneity of hMPV strains in the country. For assessing prevalence, susceptible age group, and genetic variation, analysis of
hMPV was initiated in addition to other respiratory pathogens in Eastern India. Even though the information is not representative for Indian subcontinent, this study provides the much lacking information on prevalence and genomic diversity of hMPVs in Eastern India.

\section{Additional material}

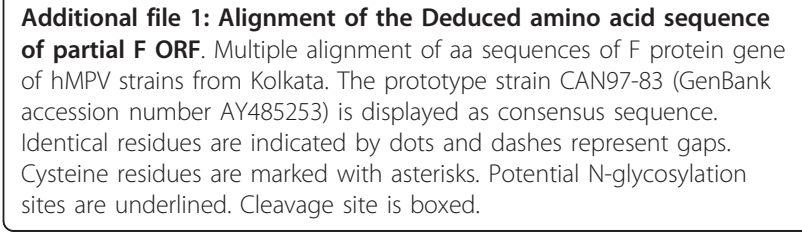

\section{Abbreviations}

aa: Amino acid; ARTI: Acute respiratory tract infection; hMPV: Human metapneumovirus; nt: Nucleotide; RSV: Respiratory Syncytial virus; RT-PCR: Reverse transcriptase-polymerase chain reaction.

\section{Acknowledgements}

The study was supported by financial assistance from Indian Council of Medical Research (ICMR), New Delhi. We acknowledge technical assistance and data entry extended by Malay De Sarkar during the study. A. S. Agrawal was supported by Senior Research Fellowship from ICMR, Govt. of India.

\section{Authors' contributions}

ASA drafted the manuscript and performed phylogenetic analysis. TR performed screening of clinical samples by RT-PCR. SG collected clinical samples and analyzed epidemiological data. MCS conceived the study, provided guidance and editing of manuscript. All authors read and approved the final manuscript.

\section{Competing interests}

The authors declare that they have no competing interests.

Received: 13 November 2010 Accepted: 12 February 2011 Published: 12 February 2011

\section{References}

1. Murray J, Loney C, Murphy LB, Graham S, Yeo RP: Characterization of monoclonal antibodies raised against recombinant respiratory syncytial virus nucleocapsid $(\mathrm{N})$ protein: identification of a region in the carboxy terminus of $\mathrm{N}$ involved in the interaction with P protein. Virology 2001, 289:252-261.

2. van den Hoogen BG, de Jong JC, Groen J, Kuiken T, de Groot R, Fouchier RA, Fouchier RA, Osterhaus AD: A newly discovered human pneumovirus isolated from young children with respiratory tract disease. Nat Med 2001, 7:719-724

3. Peret TC, Boivin G, Li Y, Couillard M, Humphrey C, Osterhaus AD, Erdman DD, Anderson $L$ : Characterization of human metapneumoviruses isolated from patients in North America. J Infect Dis 2002, 185(11):1660-1663.

4. Stockton J, Stephenson I, Fleming D, Zambon M: Human metapneumovirus as a cause of community-acquired respiratory illness. Emerg Infect Dis 2002, 8:897-901.

5. Bastien N, Normand S, Taylor T, Ward D, Peret TC, Boivin G, Anderson LJ, Li Y: Sequence analysis of the N, P, M and F genes of Canadian human metapneumovirus strains. Virus Res 2003, 93:51-62.

6. Osterhaus A, Fouchier R: Human metapneumovirus in the community. Lancet 2003, 361:890-891.

7. van den Hoogen BG, Bestebroer TM, Osterhaus ADME, Fouchier RAM: Analysis of the genomic sequence of a human metapneumovirus. Virology 2002, 295:119-132.

8. Hall CB, Walsh EE, Long CE, Schnabel KC: Immunity to and frequency of reinfection with respiratory syncytial virus. J Infect Dis 1991, 163:693-698. 
9. Levine S, Klaiber-Franco R, Paradiso PR: Demonstration that glycoprotein G is the attachment protein of respiratory syncytial virus. J Gen Virol 1987, 68:2521-2524.

10. Biacchesi S, Skiadopoulos MH, Boivin G, Hanson CT, Murphy PR, Collins PL, Buchholz UJ: Genetic diversity between human metapneumovirus subgroups. Virology 2003, 315:1-9.

11. Van Den Hoogen BG, Herfst S, Sprong L, Cane PA, Forleo-Neto E, de Swart RL, Osterhaus AD, Fouchier RA: Antigenic and genetic variability of human metapneumoviruses. Emerg Infect Dis 2004, 10:658-666.

12. Ludewick H, Abed Y, van Niekerk N, Boivin G, Klugman K, Madhi S: Human metapneumovirus genetic variability, South Africa. Emerg Infect Dis 2005, 11:1074-1078

13. Huck B, Scharf G, Neumann-Haefelin D, Weigl J, Falcone V: Novel human metapneumovirus sublineage. Emerg Infect Dis 2006, 12:147-150.

14. Gerna G, Campanini G, Rovida F, Sarasini A, Lilleri D, Paolucci S, Marchi A, Baldanti F, Revello MG: Changing circulation rate of human metapneumovirus strains and types among hospitalized pediatric patients during three consecutive winter-spring seasons. Arch Virol 2005, 150:2365-2375.

15. Agapov E, Sumino KC, Gaudreault-Keener M, Storch GA, Holtzman MJ: Genetic variability of human metapneumovirus infection: Evidence of a shift in viral genotype without change in illness. J Infect Dis 2006, 193:396-403.

16. MacKay IM, Bialasiewicz S, Jacob KC, McQueen E, Arden KE, Nissen MD, Sloots TP: Genetic diversity of human metapneumovirus over 4 consecutive years in Australia. J Infect Dis 2006, 193:396-403.

17. Skiadopulos M, Biacchesi S, Buchholz U, Roggs J, Surman S, AmaroCarambotE, McAuliffe J, Elkins W, St Claire M, Collins P, Murphy B: The two major Human Metapneumovirus genetic lineages are highly related antigenically, and the Fusion (F) protein is a major contributor to this antigenic relatedness. J Virol 2004, 78:6927-6937.

18. Johnson PR, Spriggs MK, Olmsted RA, Collins PL: The G glycoprotein of human respiratory syncytial viruses of subgroups $A$ and $B$ : Extensive sequence divergence between antigenically related proteins. Proc Natl Acad Sci USA 1987, 84:5625-5629.

19. Ahmad OB, Lopez $A D$, Inoue $M$ : The decline in child mortality: a reappraisal. Bull WHO 2000, 78:1175-1191.

20. Reddaiah VP, Kapoor SK: Acute respiratory infections in rural under fives. Ind J pediatr 1988, 35:424-426.

21. Williams BG, Gouws E, Boschi-Pinto C, Bryce J, Dye C: Estimates of worldwide distribution of child deaths from acute respiratory infections. Lancet Infect Dis 2002, 2:25-32.

22. Agrawal AS, Sarkar M, Chakrabarti S, Rajendran K, Kaur H, Mishra AC, Chatterjee MK, Naik TN, Chadha MS, Chawla-Sarkar M: Comparative evaluation of real-time PCR and conventional RT-PCR during a 2 year surveillance for influenza and respiratory syncytial virus among children with acute respiratory infections in Kolkata, India, reveals a distinct seasonality of infection. J Med Microbiol 2009, 58:1616-1622.

23. Agrawal AS, Sarkar M, Ghosh S, Roy T, Chakrabarti S, Lal R, Mishra AC, Chadha MS, Chawla-Sarkar M: Genetic characterization of circulating seasonal Influenza A viruses (2005-2009) revealed introduction of oseltamivir resistant H1N1 strains during 2009 in eastern India. Infect Genet Evol 2010, 10:1188-1198.

24. Banerjee S, Bharaj P, Sullender W, Kabra SK, Broor S: Human metapneomovirus infections among children with acute respiratory infections among children with acute respiratory infections seen in a large referral hospital in India. J Clin Virol 2007, 38:70-72.

25. Vabret A, Legrand L, Dina J, Gouarin S, Petitjean-Lecherbonnier J, Pozzetro B, Ginevra C, Freymuth F: Development of three multiplex RTPCR assays for the detection of 12 respiratory RNA viruses. J Virol Methods 2005, 126:53-63.

26. Lund O, Tolstrup N, Gooley AA, Williams KL, Brunak S: NetOglyc: prediction of mucin type O-glycosylation sites based on sequence context and surface accessibility. Glycoconjugate J 1998, 15:115-130.

27. Gupta $\mathrm{R}$, Jung $\mathrm{E}$, Brunak $\mathrm{S}$ : Prediction of $\mathrm{N}$-glycosylation sites in human proteins. NetNGlyc 1.02004 [http://www.cbs.dtu.dk/services/NetNGlyc/].

28. Kumar S, Dudley J, Nei M, Tamura K: MEGA: A biologist-centric software for evolutionary analysis of DNA and protein sequences. Briefings in Bioinformatics 2008, 9:299-306.
29. Peret TC, Abed Y, Anderson LJ, Erdman DD, Boivin G: Sequence polymorphism of the predicted human metapneumovirus $G$ glycoprotein. J Gen Virol 2004, 85:679-686.

30. Lopez JA, Bustos R, Orvell C, Berois M, Arbiza J, Garcia-Barreno B, Melero JA: Antigenic structure of human respiratory syncytial virus fusion glycoprotein. J Virol 1998, 72:6922-6928.

31. Organizacion Panamericana de la Salud (OPS): Infecciones respiratorias agudas en las Ameracas. Biol Epidemiol 1995, 16:1-5.

32. Boivin G, De Serres G, Côté $S$, Gilca R, Abed Y, Rochette L, Bergeron MG Déry P: Human metapneumovirus infections in hospitalized children. Emerg Infect Dis 2003, 9(6):634-640.

33. Prins JM, Wolthers KC: Human metapneumovirus: a new pathogen in children and adults. Neth J Med 2004, 62:177-179.

34. Van den Hoogen BG, van Doornum GJ, Fockens JC, Cornelissen JJ, Beyer WE, de Groot R, Osterhaus AD, Fouchier RA: Prevalence and clinical symptoms of human metapneumovirus infection in hospitalized patients. J Infect Dis 2003, 188:1571-1577.

35. Boivin G, Mackay I, Sloots TP, Madhi S, Freymuth F, Wolf D, Shemer- Avni Y, Ludewick H, Gray GC, LeBlanc E: Global genetic diversity of human metapneumovirus fusion gene. Emerg Infect Dis 2004, 10:1154-1157.

36. Falsey AR, Erdman D, Anderson $L$, Walsh EE: Human metapneumovirus infections in young and elderly adults. J Infect Dis 2003, 187:785-90.

37. Luchsinger $V$, Escobar $C$, Avendan o L: Deteccio'n de metapneumovirus humano en nin os hospitalizados por infeccio'n respiratoria aguda baja en Santiago, Chile (hMPV en Chile). Rev Me'd Chile 2005, 133:1059-1064.

38. Galiano M, Videla C, Puch SS, Martinez A, Echavarria M, Carballal G: Evidence of human metapneumovirus in children in Argentina. J Med Virol 2004, 72:299-303.

39. Freymuth F, Vabret A, Legrand L, Eterradossi N, Lafay-Delaire F, Brouard J, Guillois B: Presence of the new human metapneumovirus in French children with bronchiolitis. Pediatr Infect Dis J 2003, 22:92-94.

40. Shek LP, Lee BW: Epidemiology and seasonality of respiratory tract virus infections in the tropics. Paediatr Respir Rev 2003, 4:105-111.

41. Esper F, Boucher D, Weibel C, Martinello RA, Kahn JS: Human metapneumovirus infection in the United States: Clinical manifestations associated with a newly emerging respiratory infection in children. Pediatrics 2003, 111:1407-1410.

42. Ishiguro N, Ebihara T, Endo R, Ma X, Kikuta H, Ishiko H, Kobayashi K: High genetic diversity of the attachment (G) protein of human metapneumovirus. J Clin Microbiol 2004, 42:3406-3414.

43. Galiano M, Trento A, Ver L, Carballal G, Videla C: Genetic Heterogeneity of $\mathrm{G}$ and $\mathrm{F}$ Protein Genes From Argentinean Human Metapneumovirus Strains. J med virol 2006, 78:631-637.

44. Garcia O, Martin M, Dopazo J, Arbiza J, Frabasile S, Russi J, Perez-Brena P, Martinez I, Garcia-Barreno B, Melero JA: Evolutionary pattern of human respiratory syncytial virus (subgroup A): Cocirculating lineages and correlation of genetic and antigenic changes in the $\mathrm{G}$ glycoprotein. J Virol 1994, 68:5448-5459.

45. Peret $T C$, Hall CB, Schnabel KC, Golub JA, Anderson LJ: Circulation patterns of genetically distinct group $A$ and $B$ strains of human respiratory syncytial virus in a community. J Gen Virol 1998, 79(Pt 9):2221-2229.

46. Martinez I, Valdes O, Delfraro A, Arbiza J, Russi J, Melero JA: Evolutionary pattern of the $G$ glycoprotein of human respiratory syncytial viruses from antigenic group B: The use of alternative termination codons and lineage diversification. J Gen Virol 1999, 80:125-130.

doi:10.1186/1743-422X-8-67

Cite this article as: Agrawal et al:: Genetic variability of attachment (G) and Fusion (F) protein genes of human metapneumovirus strains circulating during 2006-2009 in Kolkata, Eastern India. Virology Journal $20118: 67$. 